\begin{tabular}{l|l|l|l}
$\begin{array}{l}\text { Case Reports in } \\
\text { Demiliatology }\end{array}$ & $\begin{array}{l}\text { Case Rep Dermatol 2010;2:173-176 } \\
\text { DOI: 10.1159/000321419 }\end{array}$ & $\begin{array}{l}\text { Published online: } \\
\text { October 21, 2010 }\end{array}$ & $\begin{array}{l}\text { O 2010 S. Karger AG, Basel } \\
\text { ISSN 1662-6567 } \\
\text { www.karger.com/cde }\end{array}$ \\
\hline
\end{tabular}

\title{
Nail Lichen Planus: Successful Treatment with Etanercept
}

\author{
N. Irla T. Schneiter E. Haneke N. Yawalkar \\ Department of Dermatology, Bern University Hospital and University of Bern, \\ Bern, Switzerland
}

\section{Key Words}

Nail lichen planus · Treatment · Biologics · Etanercept

\begin{abstract}
Background: Etanercept is a fully human tumor necrosis factor a receptor fusion protein that binds tumor necrosis factor a with greater affinity than natural receptors. Biologics are widely used in the treatment of psoriasis and psoriasis arthritis and may represent a new therapeutic option for some patients with psoriatic nail disease.

Case Report: We report a case of lichen planus limited to the toe nails successfully treated with etanercept monotherapy.

Conclusion: The significant improvement of our case suggests that etanercept is an effective treatment modality for lichen planus limited particularly to the nails. Further controlled studies are needed to establish the effectiveness and therapeutic regimes.
\end{abstract}

\section{Introduction}

Lichen planus (LP) is an inflammatory skin disorder with great polymorphism of its clinical appearance. Nail involvement occurs in $10 \%$ of patients with disseminated disease and may also develop in the absence of cutaneous symptoms as a destructive inflammatory onychodystrophy [1]. Treatment of nail LP is difficult and disappointing. Biological therapies are now widely used for moderate to severe chronic plaque psoriasis and psoriasis arthritis. A number of recent reports have been published on the use of biologics such as tumor necrosis factor (TNF)-antagonists (e.g. etanercept [2], infliximab $[3,4])$ as new therapeutic option for psoriatic nail disease.

\section{Case Report}

A 53-year-old Caucasian woman was referred to our department for evaluation of onychodystrophy involving multiple fingers and toe nails. The painful nail changes had progressively appeared over the past 5 years and were extremely disabling in daily living activities. Except for an atopic constitution with chronic eczema and seasonal allergic rhinoconjunctivitis, her past medical history was noncontributory and she was not on any regular systemic medication. Clinical examination of the affected nails showed 
onychodystrophy, discoloration, subungual hyperkeratosis as well as some longitudinal ridging, striation, splitting and thinning (fig. 1). The diagnosis of nail LP was made based on these clinical features. The patient had no other evidence of skin or mucosal involvement of LP or psoriasis. Since several topical treatments, including potent topical steroids, topical cyclosporine, tazarotene cream and systemic retinoids, had been ineffective, treatment with systemic cyclosporine $250 \mathrm{mg} / \mathrm{day}$ ( $3 \mathrm{mg} / \mathrm{kg}$ body weight) was initiated, which lead to significant improvement of most nails. However, since the patient developed arterial hypertension, treatment with cyclosporine was discontinued after 3 years. A relapse particularly of her toe nails occurred within a few weeks. Therapy with etanercept $(25 \mathrm{mg}$ s.c. twice weekly for the first 6 months and $50 \mathrm{mg}$ s.c. once weekly thereafter) was then initiated, which again lead to a marked improvement of her toe nail lesions within 6-9 months (fig. 2). Therapy was well tolerated with no side-effects.

\section{Discussion}

LP is considered to be a T-cell mediated autoimmune skin disease, in which autoreactive CD8+ cytotoxic T lymphocytes are key effectors through the induction of keratinocyte lesions [5]. There is one report of a patient with refractory oral and cutaneous LP who experienced significant improvement after therapy with efalizumab [6]. Another report on the use of alefacept in two patients with LP showed a dramatic response of all skin lesions [7]. Etanercept is a fully human TNF- $\alpha$ receptor fusion protein that binds TNF- $\alpha$ with greater affinity than natural receptors. It is approved for the treatment of rheumatoid arthritis, juvenile rheumatoid arthritis, ankylosing spondylitis, psoriasis and psoriasis arthritis in the USA, Canada and Europe. One case of severe erosive LP was reported to be improved by etanercept [8]. On the other hand, a case of LP occurring during etanercept therapy for rheumatoid arthritis was described, indicating that anti-TNF- $\alpha$ therapy may also be associated with the paradoxical induction of inflammatory disease such as psoriasis eruptions [9].

The significant improvement of our case suggests that etanercept is an effective treatment option for LP limited to the nails. Further controlled studies are warranted to determine more accurately both the effectiveness and therapeutic regimes of etanercept in this indication.

\section{Disclosure Statement}

Dr. Yawalkar has served as a consultant to Pfizer. 


\begin{tabular}{c|l|l|l}
$\begin{array}{c}\text { Case Reports in } \\
\text { Demillatology }\end{array}$ & $\begin{array}{l}\text { Case Rep Dermatol 2010;2:173-176 } \\
\text { DOI: 10.1159/000321419 }\end{array}$ & $\begin{array}{l}\text { Published online: } \\
\text { October 21, 2010 }\end{array}$ & $\begin{array}{l}\text { O 2010 S. Karger AG, Basel } \\
\text { ISSN 1662-6567 } \\
\text { www.karger.com/cde }\end{array}$ \\
\hline
\end{tabular}

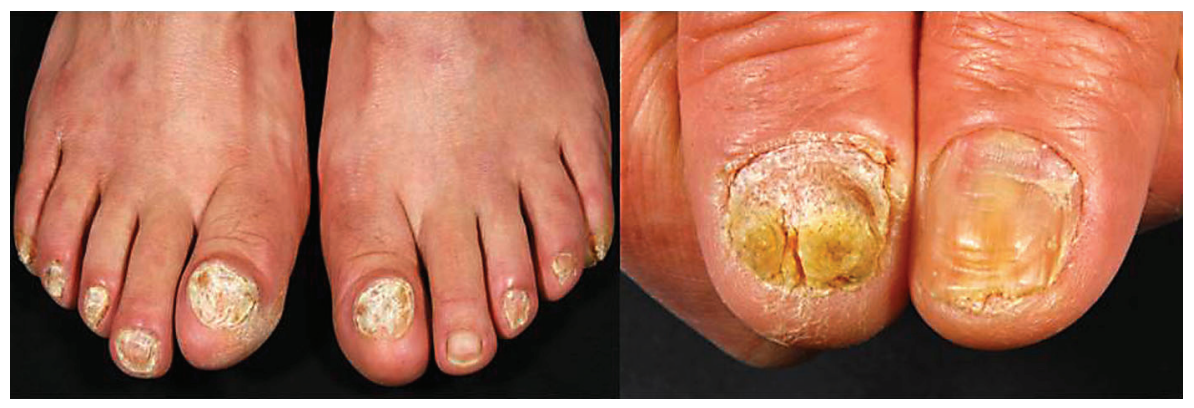

Fig. 1. Clinical features at presentation.
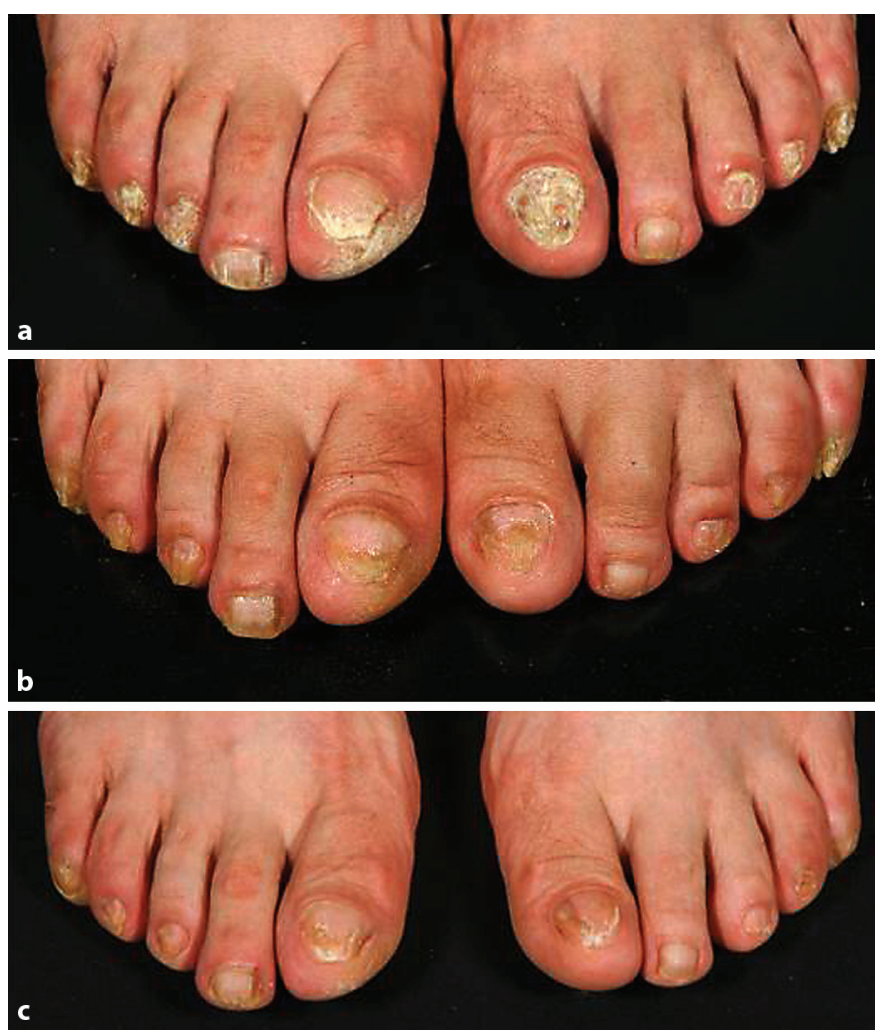

Fig. 2. Clinical findings of the patient before (a), 3 months (b) and 9 months (c) after etanercept monotherapy ( $25 \mathrm{mg}$ s.c. twice weekly for the first 6 months and $50 \mathrm{mg}$ s.c. once weekly thereafter). 


\section{References}

1 Samman PD: The nails in lichen planus. Br J Dermatol 1961;73:288-292.

2 Rallis E, Stavropoulou E, Rigopoulos D, Verros C: Rapid response of nail psoriasis to etanercept. J Rheumatol 2008;35:544-545.

3 Rich P, Griffiths CE, Reich K, et al: Baseline nail disease in patients with moderate to severe psoriasis and response to treatment with infliximab during 1 year. J Am Acad Dermatol 2008;58:224-231.

4 Rigopoulos D, Gregoriou S, Stratigos A, et al: Evaluation of the efficacy and safety of infliximab on psoriatic nails: an unblinded, nonrandomized, open-label study. Br J Dermatol 2008;159:453-456.

5 Wenzel J, Scheler M, Proelss J, Bieber T, Tuting T: Type I interferon-associated cytotoxic inflammation in lichen planus. J Cutan Pathol 2006;33:672-678.

6 Cheng A, Mann C: Oral erosive lichen planus treated with efalizumab. Arch Dermatol 2006;142:680-682.

7 Fivenson DP, Mathes B: Treatment of generalized lichen planus with alefacept. Arch Dermatol 2006;142:151152.

8 Sheth N, et al: Fatal erosive lichen planus. Br J Dermatol 2006;55:1075-1076.

9 Battistella M, Rivet J, Bachelez H, Liote F: Lichen planus associated with etanercept. Br J Dermatol 2008;158:188-190. 